\title{
Dynamics of abscission of reproductive structures in common bean access
}

\author{
Dinâmica da abscisão de estruturas reprodutivas em acessos de feijoeiro comum
}

\author{
Nicole Orsi ${ }^{1}$, Caroline Moraes ${ }^{2}$, Ana Carolina da Costa Lara-Fioreze ${ }^{2}$, Samuel Luiz Fioreze ${ }^{2 *}$ \\ ${ }^{1}$ Escola Superior de Agricultura "Luiz de Queiroz", Piracicaba, SP, Brasil. \\ ${ }^{2}$ Universidade Federal de Santa Catarina, Curitibanos, SC, Brasil. * Author for correspondence: s.fioreze@ufsc.br
}

Submission: 10/06/2020 / Acceptance: 21/12/2020

\begin{abstract}
Genotypes from the Andean and Mesoamerican gene pool can present contrasting behavior for reproductive structures fixation. The subject of this study was to determine the dynamics associated with the abscission of reproductive structures for common bean accesses from Andean and Mesoamerican gene pools in protected cultivation conditions. The experiment was carried out in a greenhouse, using seven common bean accesses from Embrapa Arroz e Feijão and the experimental design consisted of a randomized complete block design. The evaluations made were based on the number of days to begin flowering, flowering period, number of emitted flowers per plant, number of flower buds, flowers and pods aborted per plant, total number of pods per plant and number of seeds per plant.Certain characteristics were considered to be highly significant, such as the amount of days to begin flowering, the flowering period, percentage of aborted pods and number of harvested pods. The Mesoamerican accesses that presented greater abortion also produced more flowers, which suggests that abortion of reproductive structures can be a natural adjustment of the plant. Andean accessions with shorter reproductive period showed greater pod abortion. The dynamics of flower and pod abscission in the common bean proved to be widely variable depending on the different gene pools and genotypes evaluated and due to growth habit.
\end{abstract}

KEYWORDS: Phaseolus vulgaris L., abscission, flower, pods, adjustment.

\section{RESUMO}

Genótipos do pool gênico andino e mesoamericano podem apresentar comportamentos contrastantes para a fixação de estruturas reprodutivas. O objetivo deste estudo foi determinar a dinâmica associada à abscisão de estruturas reprodutivas para acessos de feijoeiro comum dos pools gênicos andino e mesoamericano em condições de cultivo protegido. O experimento foi conduzido em casa de vegetação, utilizando-se sete acessos de feijoeiro da Embrapa Arroz e Feijão e o delineamento experimental foi em blocos casualizados. As avaliações feitas foram o número de dias para o início da floração, período de floração, número de flores emitidas por planta, número de botões florais, flores e frutos abortados por planta, número total de frutos por planta e número de sementes por planta. Observou-se significância para as características de dias para início do florescimento, período de floração, porcentagem de vagens abortadas e número de vagens colhidas. Os acessos mesoamericanos que apresentaram maior aborto também produziram mais flores, o que sugere que 0 aborto de estruturas reprodutivas pode ser um ajuste natural da planta. Acessos andinos com menor período reprodutivo, apresentaram maior aborto de frutos. A dinâmica de abscisão da flor e da vagem no feijoeiro mostrou-se amplamente variável dependendo dos diferentes pools gênicos e genótipos avaliados, devido ao hábito de crescimento.

PALAVRAS-CHAVE: Phaseolus vulgaris L., abscisão, flores, vagens, ajuste.

\section{INTRODUCTION}

Abscission is considered a genetically controlled process that consists on the segregation of a determined organ, or part of it, from the plant through programmed cell death of a specific group of cells, creating the abscission zone (SEXTON \& ROBERTS 1982). The abortion of flower buds or flowers is considered a natural event for most plant species. The intensity of reproductive structure losses can be influenced as much by genotype as by environmental conditions (HUFF \& DYBING 1980). 
Beyond plant density, the main yield components in the common bean are number of pods per plant, number of grains per pod and weight of 100 grains. The number of pods fixed depends on the number of flowers emitted and percentage of flowers or pod abortion. In soybean plants, for example,abscission can occur even in pollinated and fertilized flowers. However, flowers with tendency to abortion grow more slowly than those that develop on pods (HUFF \& DYBING 1980). In addition, seed fixation is determined by the number of ovules per flower, by the frequency of aborted embryos and by the number of pods per plant (TISCHNER et al. 2003). Several studies show the genetic basis of abscission of organs during the development of seeds. Low levels of fertility in some species was observed due to genetically programmed abortion of young embryos (WIENS 1984). The number of ovules and the abortion of embryos are examples of quantitative traits that result from the interaction between genotype and environment (TANKSLEY 1993).

The fixation of reproductive structures in the common bean is influenced by several climatic conditions. Temperatures higher than $30{ }^{\circ} \mathrm{C}$ results in flowers and young pod abortion, while temperatures lower than $11^{\circ} \mathrm{C}$ can reduce the number of pods per plant (FARLOW 1981, SILVA et al. 2006). In relation to water availability, the critical period for water stress occurs between flowering and grain filling (GOMES et al. 2000). However, the most harmful effects are observed mainly in the interaction between water restriction and high temperatures. In addition, factors such as mineral nutrition and the occurrence of pests may also contribute to the reproductive success of the common bean (ZILIO et al. 2011).

Common bean genotypes can differ in their tolerance to heat stress in field conditions or greenhouse conditions (MONTERROSO \& WIEN 1990). Even in not stressful conditions, flower abscission can reach up to $70 \%$ for Mesoamerican beans at field conditions (MARTINS et al. 2017). Andean and Mesoamerican gene pools differ in many traits such as seed size, growth habit and tolerance to environmental stresses. Genetic variability between genic pools can also occur for reproductive structure fixation (SINGH et al. 1991). Thus, this study aimed to gain further knowledge on the emission and abscission profiles of reproductive structures of common bean accesses from Andean and Mesoamerican gene pools under greenhouse conditions.

\section{MATERIAL AND METHODS}

The study was carried out at the Universidade Federal de Santa Catarina (UFSC) (Curitibanos, Santa Catarina state, Brazil) under greenhouse conditions. Seven common bean accesses from Embrapa Arroz e Feijão Active Germplasm Bank were used, four from the Andean and three from the Mesoamerican gene pool (Figure 1 and Table 1).

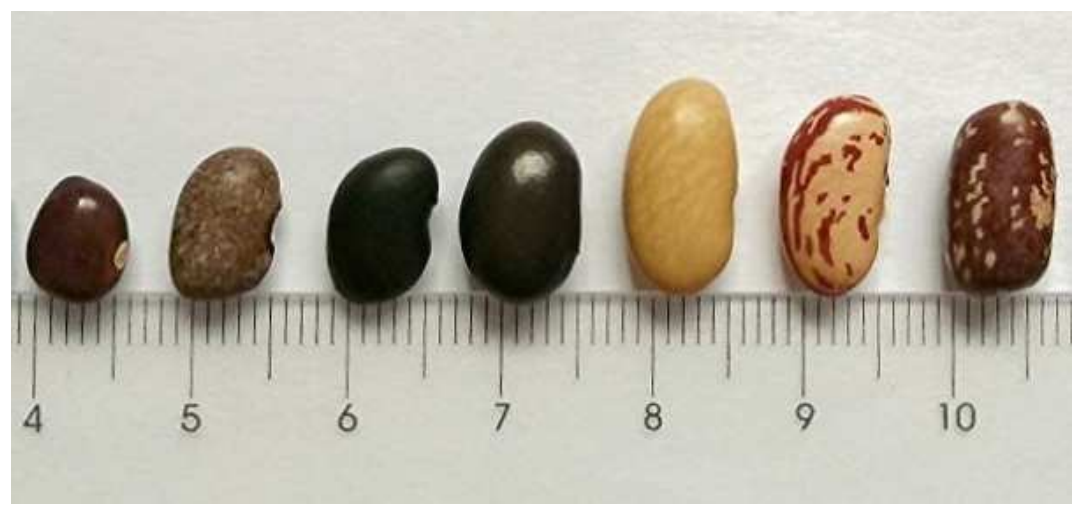

Figure 1. Accesses from Embrapa Arroz e Feijão Active Germplasm Bank (AGB). From left to right: 'Crioulo Miúdo', 'Mourinho', 'Preto de Copa', 'Ligeiro', 'Enxofre', 'Cavalo' and 'Rajado'.

Table 1. Description of accesses from AGB - Embrapa Arroz e Feijão.

\begin{tabular}{cccccc}
\hline Number & № AGB & Identification & Gene pool & Grain color' & Site of origin \\
\hline 1 & BGF16020 & 'Crioulo Miúdo' & Mesoamerican & Black & Campos Novos/SC \\
2 & BGF12791 & 'Mourinho' & Mesoamerican & Others & Rio das Antas/SC \\
3 & BGF12881 & 'Preto de Copa' & Mesoamerican & Black & Caxambu do Sul/SC \\
4 & BGF12816 & 'Ligeiro' & Andean & Black & Videira/SC \\
5 & BGF12871 & 'Enxofre' & Andean & Yellow & Chapecó/SC \\
6 & BGF12863 & 'Cavalo' & Andean & Beige with pink stripes & Coronel Freitas/SC \\
7 & BGF16037 & 'Rajado' & Andean & Beige with brown stripes & São Carlos/SC \\
\hline
\end{tabular}

${ }^{1}$ Classification based on Document 184 - Minimum descriptors indicated to characterize cultivars / varieties of common bean (Phaseolus vulgaris L.) from Embrapa Arroz e Feijão (SILVA 2005). 
The experimental design consisted of a randomized block design with three replications. Each experimental unit consisted of a $5 \mathrm{dm}^{3}$ polyethylene pot filled with a limed soil and cultivated with a plant, after thinning. The soil was Cambissolo Háplico típico (Brazilian classification; SANTOS et al. 2013) or inceptisol, with a clayey texture (550 g clay kg-1). Common bean accesses were sown in March 2016 . Base fertilization was mixed with the soil and consisted of $25 \mathrm{mg} \mathrm{dm}^{-3}$ of nitrogen (urea) $78 \mathrm{mg} \mathrm{dm}^{-3}$ of potassium $(\mathrm{KCl}), 678 \mathrm{mg} \mathrm{dm}^{-3}$ of phosphate (triple superphosphate). Side dressing nitrogen fertilization was carried out at third leaf stage.

A 60 × $60 \mathrm{~cm}$ sheet of paper was placed under each pot to collect the aborted reproductive structures. The dynamics of emission and abscission of reproductive structures were studied daily, in order to determine: number of days to begin flowering, the flowering period (from the first to last flower opened), number of flowers produced per plant, number of flower buds aborted per plant, the number of open and closed flowers aborted per plant, the number of aborted pods per plant (Figure 2). At the end of the crop cycle, the numbers of pods and seeds per plant were also determined.

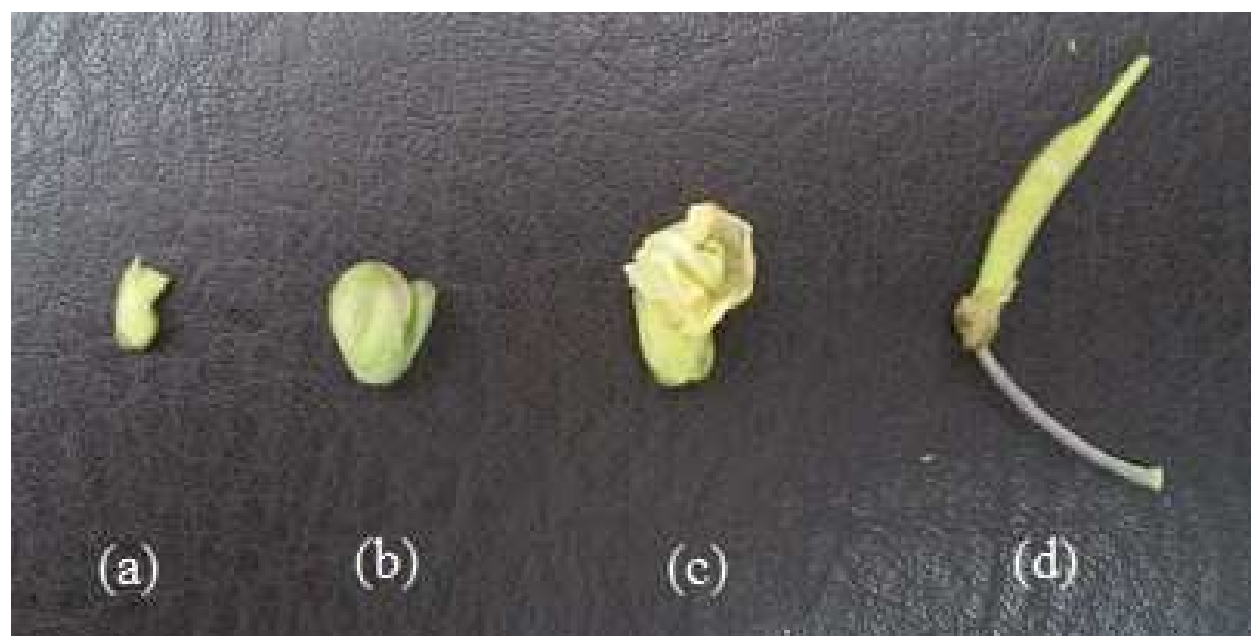

Figure 2. Forms of abscission in common bean accesses under greenhouse conditions: flower buds (a), closed flowers (b), open flowers (c) and pods (d) at Curitibanos, SC, 2016.

Data were subjected to individual univariate analysis of variance using the $F$ test $(p<0.10)$. Means were clustered by the Scott-Knott test $(p<0.10)$. Additionally, Pearson Correlation analysis was realized, using the t test $(p<0.05)$. Analyses were performed using Sisvar software (FERREIRA 2011).

\section{RESULTS AND DISCUSSION}

Statistical difference for number of days to begin flowering and flowering period $(p<0.01)$, percentage of aborted pods $(p<0.10)$ and number of harvested pods $(p<0.05)$ were observed. Ligeiro presented the lowest value, followed by Cavalo and Rajado accesses. (Andean pool) showed a shorter period between emergence and beginning of flowering when compared to the other accesses (Figure 3). The difference between earlier (Ligeiro) and later (Crioulo Miúdo) access was eight days. Although it belongs to the Andean group, access Enxofre was grouped with the Mesoamerican accesses of this trait. With the exception of Enxofre, there was a very cleardistinction between the gene pools. For the flowering period, accesses were separated in two groups. This period ranged between 13 (Rajado) and 18 (Cavalo) days in Andean accesses and between 21 (Preto de Copa) and 27 days in Mesoamerican accesses (Crioulo Miúdo).

Differences between genic pools for the flowering period can be explained by growth habit. Andean accessions showed a habit of determined growth and the Mesoamericans had a habit of indeterminate growth. Accesses with indeterminate growth continue their vegetative growth after the beginning of the flowering period until the appearance of the last nodes, at the plants' apex. Common bean genotypes with indeterminate habit, as they have a longer flowering period, are considered to be more stable or more tolerant to environmental stresses, and may present a strategy of balance in flower production. Additionally, the aforementioned are genotypes with a longer cycle and may present uneven maturation. Considering that early flowers are stronger sinks of assimilates, compared to late flowers, long flowering periods increase competition between sinks for assimilates from photosynthesis, leading to abscission in late flowers. This competition becomes stronger according to the period duration and the amount of assimilates available (EGLI \& BRUENING 2006). However, it is still not clear the impact of these aspects to yield (FAKIR et al. 2011). 


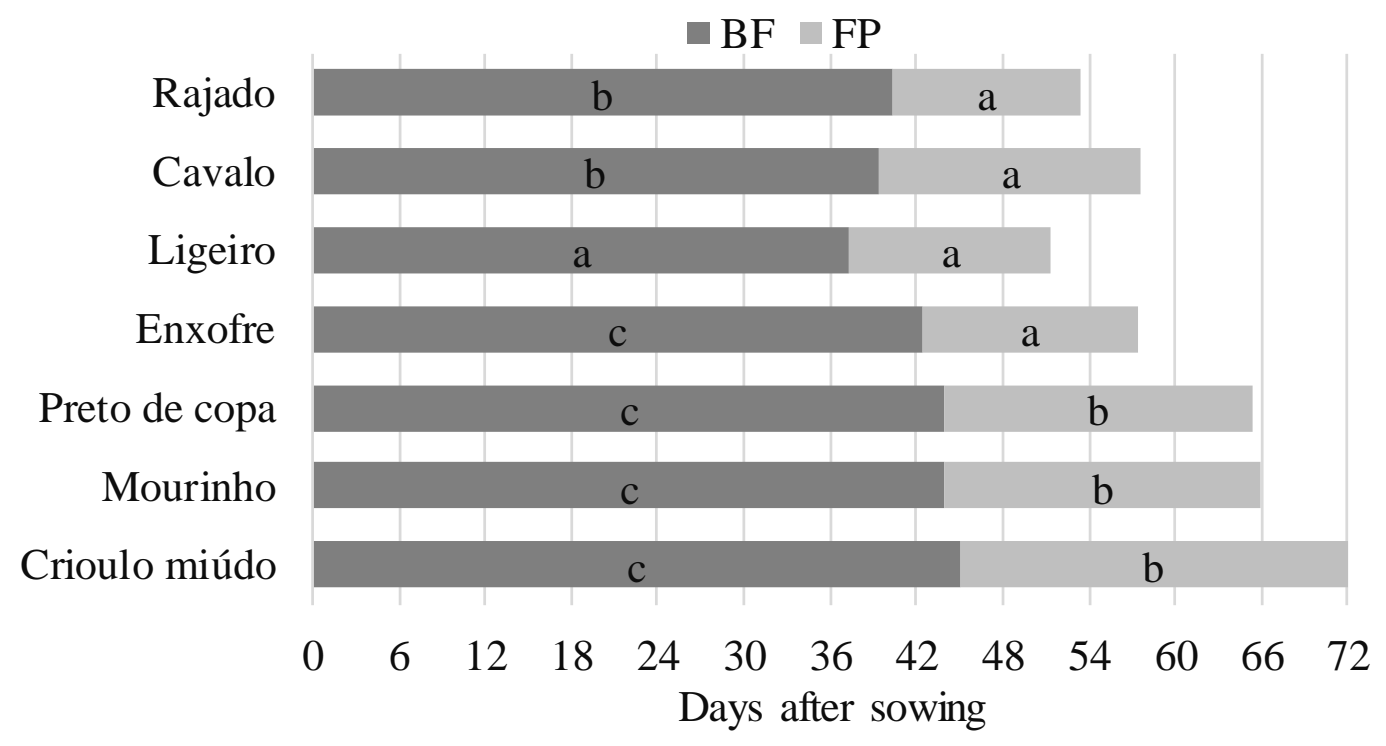

Figure 3. Beginning of flowering (BF) and period of flowering (FP) on accessions of common bean. Curitibanos, SC, 2016. Means followed by the same letter do not differ by the Scott-Knott test $(p<0.01)$.

Flower abscission was understood as the abscission of flower buds and closed flowers (Figure 2a and $2 b)$ and the abscission open flowers (Figure 2c). There was no statistical difference for number of aborted flowers (open and closed) and bud flowers. Variance from 3 to 7 reproductive structures aborted per plant, however, was observed. The lowest values were observed for Ligeiro (Andean pool) and the highest value for Crioulo Miúdo (Mesoamerican pool). The number of open flowers aborted ranged from 3 (Andean pool) to 8 (Mesoamerican pool) per plant (Figure 4).

The number of emitted flowers for common bean accesses is presented in Figure 4. Despite no statistical difference, Mourinho access emitted 32 flowers per plant and even though with highest number of open flowers aborted it showed the highest value for flower retention. Crioulo Miúdo access showed similar behavior, despite the smaller amount of flowers retained. Enxofre showed the lower value for flower emission (22 flowers). Accesses with low flower emission were from Andean gene pool while accesses with higher emission were from Mesoamerican gene pool. These results can be explained, again, by growth habit, being that Andean genotypes show a determinate growth (Type I). MARTINS et al. (2017), evaluating flower emission in common bean, obtained an average of 31.9 per plant, with the highest values for Mesoamerican genotypes. According to YAMAN (1994) the number of flowers produced per plant in common bean range from 21.23 to 52.40 .

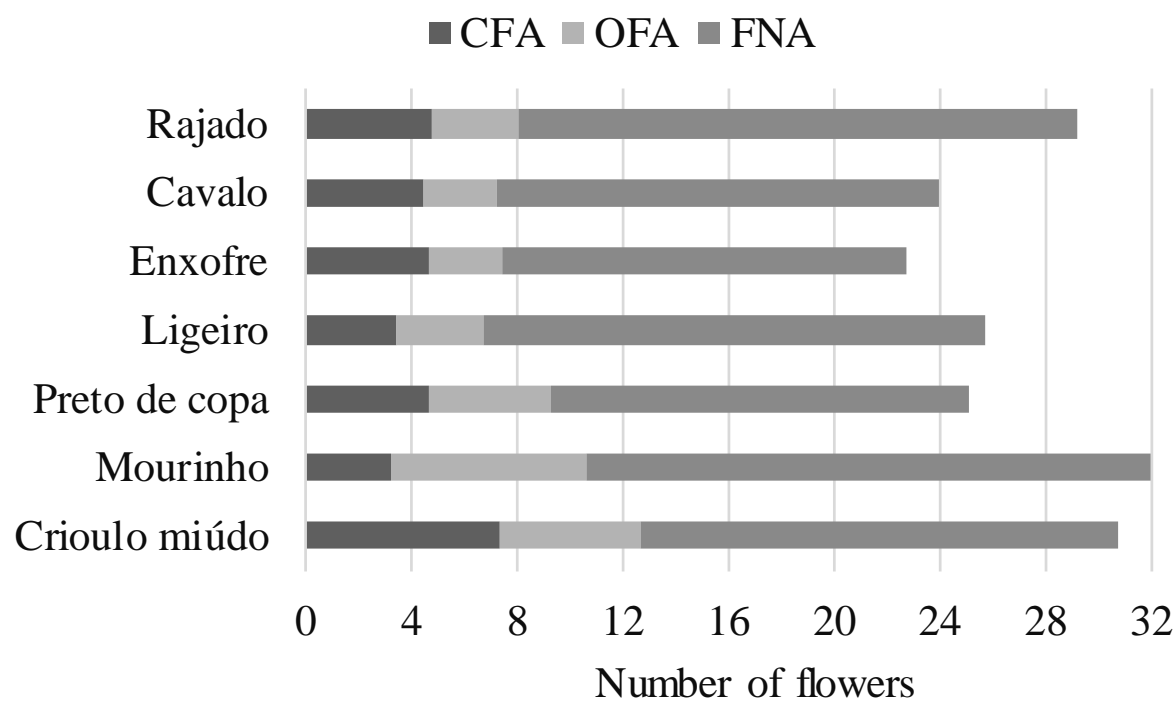

Figure 4. Closed flowers aborted (CFA), open flowers aborted (OFA) and flowers not aborted (FNA) in accessions of common bean. Curitibanos, SC, 2016. 
There was no statistical difference for percentage of aborted flowers (open and closed) and bud flowers. Mourinho access (Andean genic pool) showed lower value for closed flowers abscission (12.4) while Cavalo (Mesoamerican genic pool) showed the highest value (25\%) (Figure 5). Open flowers aborted ranged from 8 to $24 \%$ so that the lowest values were observed for Andean accesses. It is possible to state that the pattern of emission and flower abortion among the gene pools is justified by the longer flowering period and the competition between early and late flowers within the same plant when in the case of Mesoamerican genotypes, due to the habit of indeterminate growth.

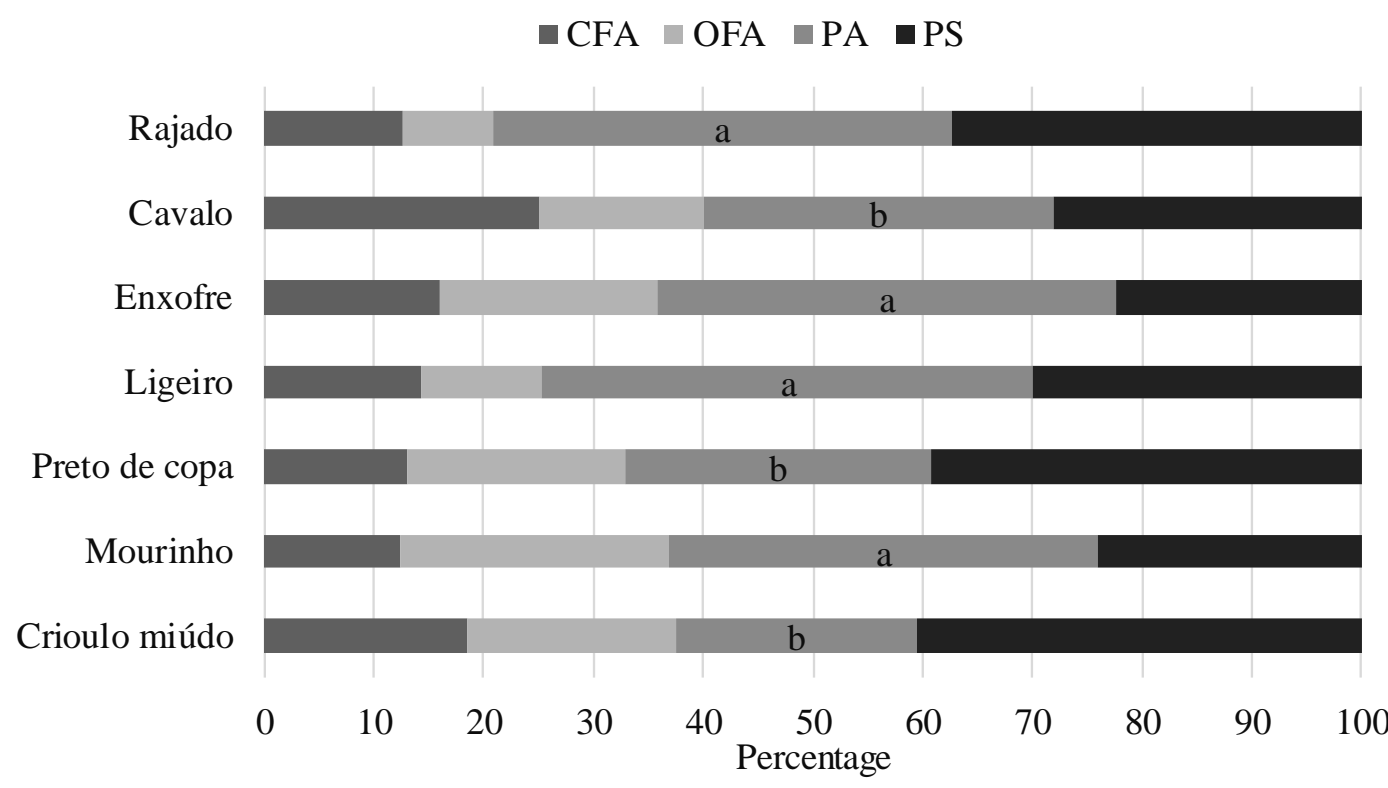

Figure 5. Percentage of closed flowers aborted (CFA), open flowers aborted (OFA), pods aborted (PA) and pod set (PS) in common bean accesses. Curitibanos, SC, 2016. Means followed by the same letter do not differ by the Scott-Knott test $(p<0.10)$.

Worthy of note, these results were obtained under greenhouse conditions, establishing a response pattern. Under limiting environmental conditions, with high temperatures, drought stress or low air moisture, abscission of reproductive structures may increase. HOFFMANN JÚNIOR et al. (2007) observed an abscission of $79 \%$ of flowers when plants were exposed to temperatures of $30{ }^{\circ} \mathrm{C}$ during flowering period. Similarly, IZQUIERDO \& HOSFIELD (1981) observed an abscission of $60.5 \%$ in the common bean plant. REIS et al. (1985) showed an increase of $11 \%$ in flower abscission of common bean flowers when intercropped with maize.

The pattern of flower abortion was demonstrated in soybean and cowpea plants through variations in the vascular development of racemes (WIEBOLD \& PANCIERA 1990, EGLI \& BRUENING 2006, MONDAL et al. 2011). Flowers emitted early, in basal positions of the racemes, are more vascularized, with better access to nutrients, assimilated and other substances. In soybean flowers, the balance between cytokinin and abscisic acid is determinant for the fixation of reproductive structures, changing vascular development of these structures (LIU et al. 2003). These traits are regulated by genetic and environmental factors, which are detrimental to the amount of nutrients, assimilated and other substances available to supply the reproductive structures.

Significant differences were observed in the percentage of aborted pods $(p<0.10)$. A variation from 22 to $44 \%$ of aborted pods was observed. The highest percentage of abortion was observed in the Ligeiro access (Andean group) while the lowest value was observed in Crioulo Miúdo (the Mesoamerican group). Accesses were separated in two groups. The group with highest values consisted of three accesses in the Andean group and one from the Mesoamerican group (Figure 5). Again, pod abscission can be explained by growth habit. Plants with determined (the Andean group) growth have a lower potential for the emission of new leaves after the beginning of flowering period. As such, the adjustment between the number of sinks and the source of assimilates can be obtained through the abscission of pods, whereas plants with indeterminate growth have greater plasticity for this adjustment.

Pod abscission is not usually addressed when it comes to the subject of abortion of reproductive structures in the common bean. The present study, however, shows that its impact is also very significant. Pod set ranged from 22.5 to $40.5 \%$ so that the lowest value was observed for the Cavalo access (Andean 
genic pool) and the highest value for Mourinho (Mesoamerican genic pool) (Figure 5). Many studies only study flower abscission in terms of percentage of fixation. MARTINS et al. (2017) observed an average of flower retention of $40.4 \%$ on common bean genotypes, with higher values for Mesoamerican gene pool. However, with the difference between the accesses for percentage of pod abortion, it is clear that this event has great importance in the final adjustment of plant yield, under limiting environmental conditions or not, proving to be a trait with genetic variability. Number of pods is an important trait in the selection of genotypes with high grain yield, considering that high rates of pod abortion reduce the performance of genotypes (CABRAL et al. 2011).

Common bean accesses differed for number of pod set (Figure 6). The values ranged from 6 (Enxofre) to 12 (Crioulo Miúdo). Two groups were formed, so that the group with the highest values was composed of two Mesoamerican accesses and one Andean access. This fact may be related to the greater abortion of pods observed for the accesses of the Andean genic pool. Abortion of pods is common in the early stages of development, especially under stress conditions. Common bean plants submitted to $35{ }^{\circ} \mathrm{C}$ for 10 hours during two days in greenhouse conditions showed greater abortion of young pods (smaller than $2 \mathrm{~cm}$ ), while pods larger than $4 \mathrm{~cm}$ were aborted less (MONTERROSO \& WIEN 1990). Similar effect with temperature is also observed in field conditions (IZQUIERDO \& HOSFIELD 1981).

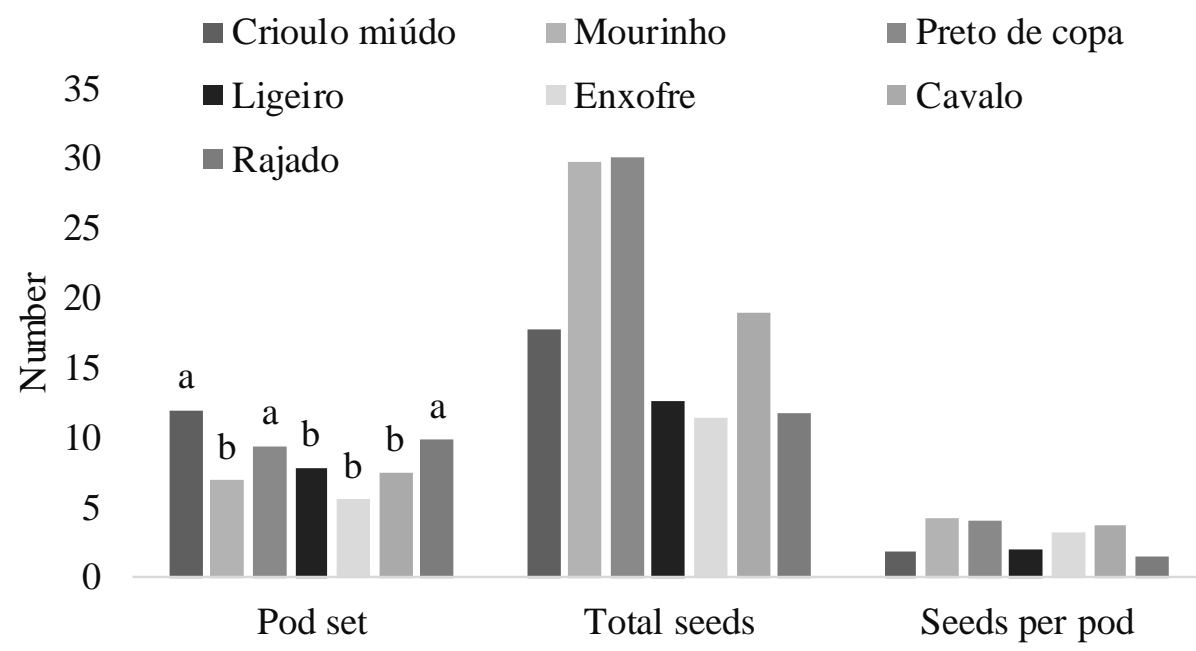

Figure 6. Number of pod set, total seeds and seeds per pod for each plant of common bean accessions. Curitibanos, SC, 2016. Means followed by the same letter do not differ by the Scott-Knott test $(p<0.05)$.

The number of seeds per plant and number of seeds per pod did not present statistical difference. However, the highest value was observed for Preto de Copa (average of 4.1 seeds per pod and 30 seeds per plant) and Mourinho (average of 4.2 seeds per pod and 29.7 seeds per plant), both from the Mesoamerican genic pool. Andean genotypes usually present the least number of seeds per pod than Mesoamerican genotypes, although they have larger seeds, considering that Andean genotypes have seeds of medium and big sizes while Mesoamerican genotypes seeds are medium or small (SALGADO et al. 2011). In the present study, only Rajado (Andean) showed different results, with an average of 1.5 seeds per pod (Figure 6). DRUN et al. (2017), observed a negative correlation between number and mass of grains per plant within the same genetic material, being possible to obtain similar values of yield (without significant differences) in plants with different number of grains, by adjusting the mass by one thousand grains.

Common bean accesses showed differences in the abortion profile of reproductive structures over the period (Figure 7). The period between the beginning of the emission of flowers and the last aborted pods varied between five and eight weeks. Crioulo Miúdo showed the longest period of abscission of flowers and, together with Preto de Copa, showed the longest period for first pod aborted (three weeks after the beginning of flowering), both from the Mesoamerican genic pool.

Mourinho (Mesoamerican) and Enxofre (Andean) accesses showed the shortest period of pod and flower abortion. Additionally, Mourinho was the only access to abscission of pods already in the first week after the beginning of flowering. Ligeiro was the access with the lowest number of aborted flowers and the shortest flowering period, but also showed the largest abortion of pods and longest period of abscission of pods. Finally, Cavalo access showed the longest period from the beginning of the flowering period to the end of abscissions. 

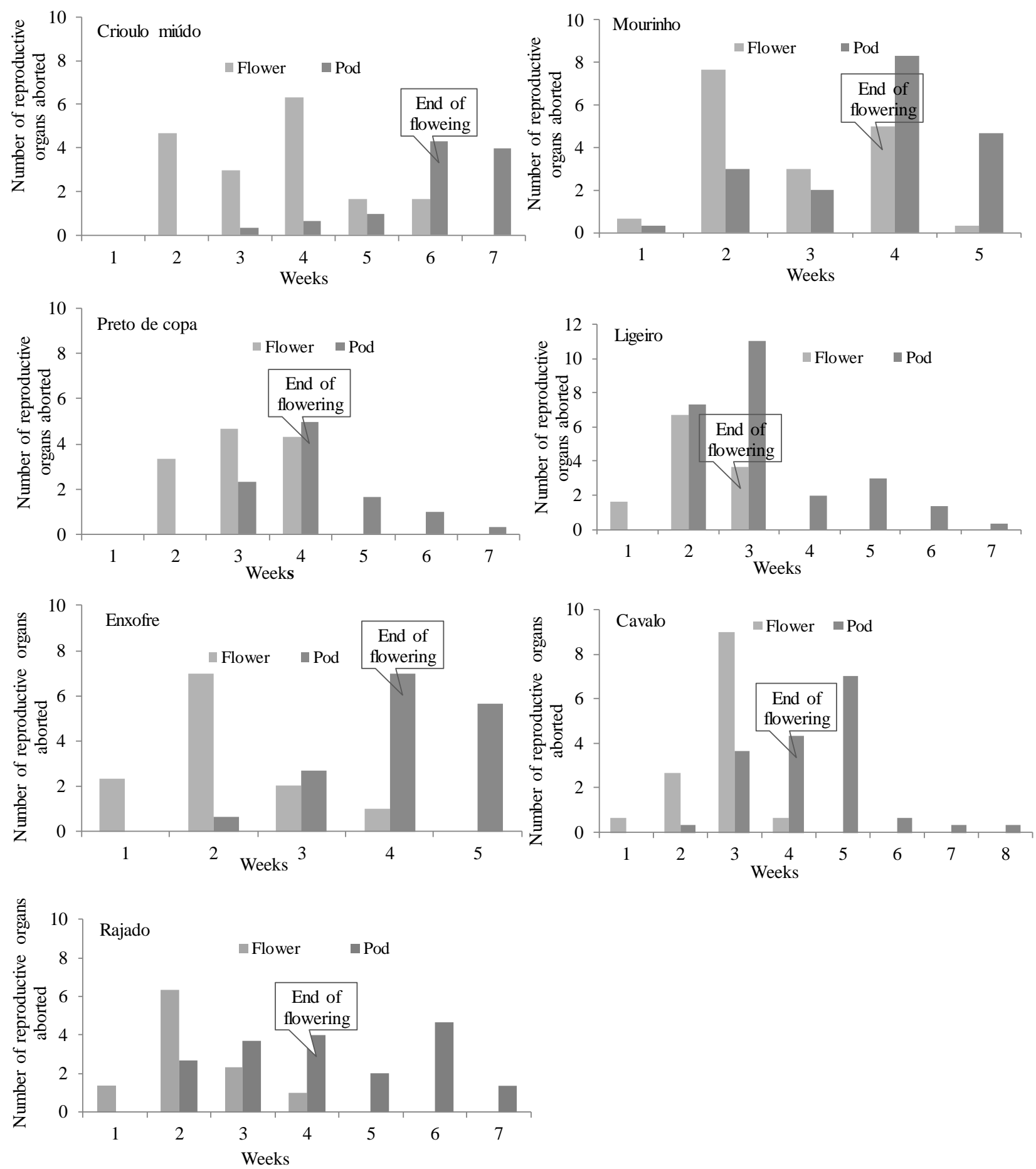

Figure 7. Temporal profile of abortion of reproductive organs (flowers and pods) in seven accesses of common bean. Curitibanos, SC, 2016.

It is possible to verify that some Mesoamerican accessions promote their adjustment through the abortion of flowers (buds, closed or open), throughout the flowering period, which is greater due to the habit of indeterminate growth, and in the case of abortion of pods, this occurs later. On the other hand, some Andean accessions promote the abortion of pods earlier in the reproductive period, showing that this is a most significant adjustment for bean genotypes with a determined growth habit.

There was a positive correlation between early flowering and duration of the flowering period, as well as the percentage of open flower abortion (Table 2). Negative correlation, however, was observed in the percentage of aborted pods. Accesses in long periods of flowering showed a higher number of open flowers aborted and a higher number of seeds harvested, as well as lower percentage of pod abortion. There was a positive correlation between number of flowers emitted and number of flowers and aborted pods. However, accesses with a higher number of flowers also presented a higher number of pods harvested, although with 
fewer seeds. Additionally, plants with a high percentage of pod abortion showed fewer pods, with a higher number of seeds. The abortion of pods, in turn, presented negative correlation with the number of seeds harvested.

Table 2. Analysis of Pearson correlation between reproductive traits in common bean.

\begin{tabular}{|c|c|c|c|c|c|c|c|c|c|c|c|c|}
\hline & FP & NFP & NCFA & PCFA & NOFA & POFA & NPA & APP & NHP & PPH & NS & NSP \\
\hline $\mathrm{BF}$ & $0,61^{\star *}$ & 0,17 & 0,25 & $-0,17$ & 0,36 & $0,47^{*}$ & $-0,13$ & $-0,53^{\star \star}$ & 0,30 & 0,25 & 0,36 & 0,16 \\
\hline FP & & 0,21 & 0,31 & 0,25 & $0,42^{*}$ & 0,38 & $-0,09$ & $-0,59^{* *}$ & 0,24 & 0,07 & $0,45^{*}$ & 0,26 \\
\hline NFP & & & $0,80^{* *}$ & $-0,07$ & $0,83^{\star *}$ & $-0,44^{\star}$ & $0,80^{* *}$ & 0,27 & $0,76^{* *}$ & 0,15 & 0,05 & $-0,53^{*}$ \\
\hline NCFA & & & & 0,34 & $0,48^{*}$ & $-0,46^{*}$ & 0,37 & $-0,13$ & $0,81^{* *}$ & 0,26 & 0,04 & $-0,49^{*}$ \\
\hline PCFA & & & & & $-0,20$ & $-0,01$ & $-0,19$ & $-0,37$ & $-0,07$ & $-0,37$ & 0,19 & 0,14 \\
\hline NOFA & & & & & & $-0,02$ & 0,76 & 0,25 & $0,45^{*}$ & $-0,09$ & 0,23 & $-0,22$ \\
\hline POFA & & & & & & & $-0,35$ & $-0,41$ & $-0,46^{*}$ & $-0,44^{*}$ & $0,53^{*}$ & $0,83^{\star *}$ \\
\hline NPA & & & & & & & & $0,73^{\star *}$ & 0,27 & $-0,28$ & $-0,09$ & $-0,36$ \\
\hline APP & & & & & & & & & $-0,23$ & $-0,37$ & $-0,49^{*}$ & $-0,33$ \\
\hline NHP & & & & & & & & & & $0,66^{* *}$ & 0,11 & $-0,56^{* \star}$ \\
\hline PPH & & & & & & & & & & & $-0,11$ & $-0,48^{*}$ \\
\hline NS & & & & & & & & & & & & $0,58^{* *}$ \\
\hline
\end{tabular}

BF: Beginning of flowering; FP: Flowering period; NFP: number of flowers produced; NCFA: number of closed flowers aborted; PCFA: percentage of closed flowers aborted; NOFA: number of open flowers aborted; POFA: percentage of open flowers aborted; NPA: number of pods aborted; APP: aborted pod percentage; NHP: number of harvested pods; PPH: percentage of pods harvested; NS: number of seeds and NSP: number of seeds per pod. ${ }^{* *}$ and * indicate significant at $1 \%$ and $5 \%$ level of probability, respectively.

PERKSEN (2007) found a positive correlation between the number of flowers and number of pods per plant and a negative correlation between number of seeds per pod and number of flowers produced in the common bean. Therefore, the number of flowers increases the number of pods, but it does not mean that yield would be higher. MADRIZ et al. (2015) found a positive correlation between number of pods per plant and number of flowers aborted, which agrees with our results. They also obtained positive correlation between yield and flowers aborted. FAKIR et al. (2011) evaluating flowering pattern on mungbeans observed a positive correlation between the flowering period and number of flowers and pods produced, which does not agree with our results, where the values were low and not significant.

The correlation between the number of flowers produced and the number of flowers aborted or between the number of pods per plant and the number of flowers aborted raises the hypothesis of a mechanism of adjust, since when a plant shows a high flower abscission, it also shows a high emission of flowers, as a way of compensation. When environmental conditions are favorable to flowering and unfavorable to grain filling, the number of flowers produced and the number of flowers aborted would be higher and flower retention would be lower (MARTINS et al. 2017), which agrees with this hypothesis. Even with adequate climatic conditions, there is abscission of reproductive organs, with different patterns among genotypes or genic pools. These patterns may be a regulation in each genotype, in order to obtain a satisfactory yield. Finally, it must be considered that when flower abortion occurs, the remaining flowers will have more assimilates available, which can maintain or even increase yield through other yield components (ASCOUGH et al. 2005).

\section{CONCLUSION}

Accessions of Andean common beans begin their flowering earlier and have a shorter flowering period, compared to Mesoamerican accessions.

Abortion of buds in open and closed flowers occurs more effectively in Mesoamerican accessions, however they produce more flowers than they do in the Andes.

The abortion of pods is more prominent in Andean accessions, and this occurs earlier in the reproductive period.

The differences observed in the pattern of abscission of reproductive structures in bean accessions are related to the type of growth habit. 


\section{REFERENCES}

ASCOUGH GD et al. 2005. Flower abscission: environmental control, internal regulation and physiological responses of plants. South African Journal of Botany 71: 287-301.

CABRAL PDS et al. 2011. Diversidade genética de acessos de feijão comum por caracteres agronômicos. Revista de Ciência Agronômica 42: 898-905.

DRUN RP et al. 2017. Parâmetros produtivos do feijão vermelho em função do tamanho de sementes. Colloquium Agrariae 13: 41-48.

FERREIRA DF. 2011. Sisvar: a computer statistical analysis system. Ciência e Agrotecnologia 35: 1039-1042.

EGLI DB \& BRUENING WP. 2006. Temporal profiles of pod production and reproductive success in soybean. European Journal of Agronomy 24: 11-18.

FAKIR MAS et al. 2011. Flowering pattern and reproductive efficiency in mungbean. International Journal of Agriculture \& Biology 13: 966-970.

FARLOW PJ. 1981. Effect of low temperature on number and location of developed seed in two cultivars of Phaseolus vulgaris French bean (L). Australian Journal of Agricultural Research 32: 325-330.

GOMES AA et al. 2000. Acumulação de biomassa, características fisiológicas e rendimento de grão em cultivares de feijoeiro irrigado e sob sequeiro. Pesquisa Agropecuária Brasileira 35: 1927-1937.

HOFFMANN JÚNIOR L et al. 2007. Resposta de cultivares de feijão à alta temperatura no período reprodutivo. Ciência Rural 37: 1543-1548.

HUFF A \& DYBING D. 1980. Factors affecting shedding of flowers in soybean (Glycine max (L.) Merrill). Journal of Experimental Botany 31: 751-762.

IZQUIERDO J \& HOSFIELD GL. 1981. A collection receptacle for field abscission studies in common beans (Phaseolus vulgaris L.). Crop Science 21: 622- 625.

LIU F et al. 2003. Loss of pod set caused by drought stress is associated with water status and ABA content of reproductive structures in soybean. Functional Plant Biology 30: 271-280.

MADRIZ P et al. 2015. Aborto de estructuras reproductivas de cultivares de caraota (Phaseolus vulgaris L.) evaluadas em cuatro localidades de Venezuela. Revista de la Facultad de Agronomía 41: 19-32.

MARTINS SM et al. 2017. Genetic control of number of flowers and pod set in common bean. Genetics and Molecular Research 16: 1-14.

MONDAL MMA et al. 2011. Deflowering effect on vasculature and yield attributes in raceme of mungbean [Vigna radiata (L.) Wilczek]. Australian Journal of Crop Science 5: 1339-1344.

MONTERROSO VA \& WIEN HC. 1990. Flower and pod abscission due to heat stress in beans. Journal of the American Society for Horticultural Science 115: 631-634.

PERKSEN E. 2007. Dynamics of flower appearance, flowering, pod and seed setting performance and their relations to seed yield in common bean (Phaseolus vulgaris L.). Pakistan Journal of Botany 39: 485-496.

REIS WP et al. 1985. Arranjos e populações do feijoeiro na consorciação com o milho. Pesquisa Agropecuária Brasileira 20: $575-584$.

SALGADO FHM et al. 2011. Comportamento de genótipos de feijão, no período da entressafra, no sul do Estado de Tocantins. Bioscience Journal 27: 52-58.

SANTOS HG et al. 2013. Sistema Brasileiro de Classificação de Solos. 4.ed. Brasília: Embrapa. 353p.

SEXTON R \& ROBERTS JA. 1982. Cell biology of abscission. Annual Review of Plant Physiology 33: 133-162.

SILVA HT. 2005. Descritores mínimos indicados para caracterizar cultivares/variedades de feijão comum (Phaseolus vulgaris L.). Santo Antônio de Goiás: Embrapa Arroz e Feijão. 32p.

SILVA VR et al. 2006. Variação na temperatura do solo em três sistemas de manejo na cultura do feijão. Revista Brasileira de Ciência do Solo 30: 391-399.

SINGH SP et al. 1991. Genetic diversity in cultivated common bean: II. Marker-Based analysis of morphological and agronomic traits. Crop Science 31: 23-29.

TANKSLEY SD. 1993. Mapping polygenes. Annual Review of Genetics 27: 205-233.

TISCHNER T et al. 2003. Genetics of seed abortion and reproductive traits in soybean. Crop Science 43: 464-473.

WIENS D. 1984. Ovule survivorship, brood size, life history, breeding systems, and reproductive success in plants. Oecologia 64: 47-53.

WIEBOLD WJ \& PANCIERA MT. 1990. Vasculature of soybean racemes with altered intraraceme competition. Crop Science 30: 1089-1093.

YAMAN M. 1994. The effect of different planting dates on yield and flower drops in dry bean cultivars. Proceedings of the Field Crops Congress of Turkey 1: 325-327.

ZILIO M et al. 2011. Contribuição dos componentes de rendimento na produtividade de genótipos crioulos de feijão (Phaseolus vulgaris L.). Revista Ciência Agronômica 42: 429-438. 